\title{
Estimation of water stress tolerance of six woody plant species
}

\begin{abstract}
As climate change becomes even more prominent, urban plantings face many challenges (e.g., drought heat island effects, poor soil, high vapor pressure deficits). Therefore, proper plant selection is increasingly essential. Six commonly planted functional landscape plants (Callicarpa americana L., Cornus sericea L., Ilex verticillata (L.) A. Gray, Itea virginica L., Rhus aromatica Aiton. and Cornus sanguinea L.) were grown in $3.8 \mathrm{~L}$ pots and put through a series of three dry down periods (August-October 2015) to analyze the drought tolerance and water use efficiency through the use of vapor pressure deficit (VPD). Evapotranspiration, growth data, and weather data were taken throughout the study. Maximum air temperature was $33.1{ }^{\circ} \mathrm{C}$ and maximum VPD was $2.4 \mathrm{kPa}$ over the course of the study. Growth data were influenced by species and drought resistance mechanisms. Cornus sanguinea and $\mathrm{R}$. aromatica demonstrated the slowest water depletion rates, the greatest water use efficiency, and highest drought tolerance when compared to other species throughout the study. Water depletion rates and initial water use was greatest in $\mathrm{C}$. americana and I. virginica across all dry down periods. Cornus sanguinea and R. aromatica are recommended for water-deficient urban landscapes while C. americana and I. virginica are not due to greater water depletion rates and decreased water use efficiency. The use of VPD to evaluate the drought tolerance of these woody species appears to effectively normalize water use rates and allow for the evaluation of species undergoing water stress.
\end{abstract}

Keywords: water conservation, drought tolerance, water use efficiency, vapor pressure deficit
Volume 5 Issue 2 - 202 |

\author{
Danesha Seth Carley,' Lauren A Gragg,' \\ Matthew J Taggart, ${ }^{3}$ Thomas W Rufty ${ }^{3}$ \\ 'NSF Center of Integrated Pest Management, North Carolina \\ State University, USA \\ ${ }^{2}$ Department of Horticultural Science, North Carolina State \\ University, USA \\ ${ }^{3}$ Department of Crop and Soil Sciences, North Carolina State \\ University, USA
}

Correspondence: Danesha Seth Carley, NSF Center for Integrated Pest Management, I730 Varsity Drive, STE I I0, Raleigh, NC, 27695, USA, Tel 9195।38I77, Tex 9195।31।14, Email dgseth2@ncsu.edu

Received: March 01, 202I | Published: March I5, 2021
Abbreviations: BPMs, best management practices; LVPD, leaf-to-air vapor pressure deficit; $\mathrm{kPa}$, Kilopascal; VPD, vapor pressure deficit; WUE, water use efficiency

\section{Introduction}

Climate change and increasing urbanization are contributing to water scarcity around the world. Periods of episodic heavy rainfall with longer periods of severe drought have become more frequent in much of the southeastern United States, while the western United States is experiencing even more extreme periods of drought. ${ }^{1}$ In response, programs such as WaterSense ${ }^{\circledR}$ developed by the USEPA in 2006 , were developed to encourage smart irrigation systems, appropriate irrigation scheduling, using irrigation certified professionals, and planting of drought tolerant species. ${ }^{2}$ Additional methods of reducing water use in the landscape include removing turfgrass, assigning watering days, using non-potable water, and using rain sensors. ${ }^{3}$

Xeriscaping is a landscape approach that addresses the growing concern for water scarcity. ${ }^{4}$ This practice creates landscapes specifically designed to reduce water inputs ${ }^{5}$ through the use of specific plants, grouping plants based on their water needs, using turf wisely, and efficient irrigation. Rain gardens are used in urban/ suburban settings as storm water best management practices (BPMs) and are generally non-irrigated depressions designed to capture and quickly filter large volumes of periodic water, and typically are not engineered. ${ }^{6}$ Storm water BMPs require appropriate plant selection to ensure the designed system functions properly and can withstand extended periods of drought. It stands to reason that drought tolerant plants are the best choice for these landscapes.

Drought tolerance is a characteristic that varies from species to species and is a reflection of increased water use efficiency (WUE), which is the rate of water consumption to biomass ${ }^{7,8}$ or net $\mathrm{CO}_{2}$ uptake divided by the current transpiration rate. ${ }^{9,10}$ In response to drought, plants use one of two physiological processes- either they continue to use water at the same rate as when it had an adequate supply and then metabolically break down leading to organ and/or whole plant death (drought avoidance); or they reduce water consumption and maintain metabolic functionality and still maintain aesthetic appeal (drought tolerance) ${ }^{8,11}$

Stomatal conductance, leaf and stem water potential, photosynthesis, and stem diameter are common methods for assessing plant water status. ${ }^{8,12}$ Plants that can maintain open stomata and transpire at reduced rates have increased WUE and are most desirable during periods of drought. ${ }^{13}$ However, most of these assessment tools are only applicable in research settings, such as in controlled environment chambers. Conversely, vapor pressure deficit (VPD), the difference between the actual amount of water vapor in the air (relative humidity) compared to what the air could hold at saturation at a given temperature, ${ }^{14-16}$ serves as a proxy for evaluating evapotranspiration rates. As ambient temperature increases so does VPD and evaporative demand. ${ }^{14,16,17}$ Vapor pressure deficit has been used as a tool for evaluating drought tolerance and genotype selection in agronomic crops such as wheat (Triticum aestivum L.), ${ }^{18}$ sorghum [Sorghum bicolor (L.) Moench], ${ }_{19}^{19}$ soybean [Glycine max (L.) Merr. ${ }^{20}$ peanuts (Arachis hypogaea L.) ${ }^{21}$ and turfgrass (Festuca arundinacea Schreb.). ${ }^{22}$

Much research has been performed to assess drought tolerance. ${ }^{23-26}$ Comparatively little VPD research has been done on woody plant species, but over the past few years this has begun to change. ${ }^{17,27}$ Montague and Bates ${ }^{27}$ evaluated the adaptability of two maple species, Acer $\mathrm{x}$ freemanii 'Autumn Blaze' and Acer truncatum for survivability in a semi-arid urban environment. Both tree species were found to 
be well adapted to high VPD as well as other urban stressors like high temperatures and low soil moisture. ${ }^{27}$ Montague et al. ${ }^{13}$ executed a similar study evaluating the performance of three shrubs: Rhus trilobata, Euonymus kiautschovicus 'Manhattan', and Cornus sericea over vegetative and non-vegetative surfaces in response to low leafto-air vapor pressure deficit (LVPD). Overall, Cornus sericea and E. kiautschovicus were found to be more sensitive to higher LVPD than R. trilobata as R. trlilobata had higher rates of stomatal conductance and water loss under non-water limiting conditions. ${ }^{13}$ Studies such as these illustrate how the use of VPD can aid in making appropriate plant selections for the landscap.

The objective of this study was to assess the suitability of six different woody shrubs commonly planted in landscapes in the Southeastern United States through the use of VPD. Water use efficiency and drought tolerance were assessed for six woody plant species through the use of VPD over three growing periods.

\section{Material and methods}

Polyhouse experiments were conducted at North Carolina State University Horticulture Field Laboratory, Raleigh, NC (35'47'29.6”'N $\left.78^{\circ} 41^{\prime} 59.9^{\prime \prime} \mathrm{W}\right)$ from 16 August to 23 October 2015 and were replicated three times.

\section{Plant material and growing conditions}

Six different functional woody shrubs were selected; five native species (Callicarpa americana L., Cornus sericea L., Ilex verticillata (L.) A. Gray, Itea virginica L., and Rhus aromatica Aiton) and one species native to Europe and western Asia (Cornus sanguinea L.).

Cornus sericea, C. sanguinea, and R. aromatica were purchased as plugs and transplanted into $3.8 \mathrm{~L}$ black smooth nursery containers (Grower's Nursery Supply, Inc., Salem, OR, U.S.) that contained Fafard 4P (Sun Gro Horticulture, Agawam, MA, U.S.) potting mix (45-53\% Canadian Sphagnum peat moss, aged pine bark, vermiculite, perlite, dolomitic lime, and a wetting agent) during the last week of June 2015. We purchased C. americana, I. verticillata, and I. virginica as $3.8 \mathrm{~L}$ liners and removed the existing potting media and repotted them into the same size nursery pots, using Fafard $4 \mathrm{P}$ potting mix, during the second week of August 2015. Roots were pruned as needed to improve establishment in the new media. The experiment was conducted in an open ended $47 \mathrm{~m}^{2}$ polyhouse with a 3 mil plastic semicircular cover $(11 \mathrm{~m}$ length $\times 4.27 \mathrm{~m}$ width and $50 \%$ shade cloth to reduce overheating during midday.

All plants were placed inside the polyhouse on benches, wellwatered, and allowed to acclimate until roots of all species occupied $\geq 50 \%$ of substrate by volume. To determine this, root balls of representative samples of each species were gently removed from the pot and examined. This study was a randomized complete block design with 8 replicates of each species in each block. One control pot containing only growing media was included in each block to measure evaporation. The first dry down began on 16 August 2015. All pots were watered to pot capacity and left to drain overnight. One block was used as a well-watered control, where we replaced water lost each day for each species.

\section{Data collection}

After 24 hours we weighed the pots daily between 0900 and $1100 \mathrm{~h}$ until the end of each dry down period using a scale (Model CTG15H, Citizen Scale). Measurements were recorded and plants were evaluated for signs of water stress (wilt, blue-gray cast, leaf senescence and abscission) daily. Once plants displayed signs of severe water stress, they were left to remain in the study for an additional $24 \mathrm{~h}$ and then removed from the study. As plants were pulled from the study, they were re-watered and maintained at pot capacity until the dry down period ended (02 September 2015). All plants were re-watered and given a period of at least one week to recover before beginning the second dry down. With the exception of lost leaves, no plants were displaying signs of water stress at the start of the second dry down. The same methods were repeated during the second (9 September to 24 September 2015) and third dry downs (7 October to 23 October 2015) until all plants were removed. After the third dry down, all plant material was destructively harvested and leaf area, substrate water content, and biomass were determined.

\section{Leaf area and dry weights}

At harvest, samples of the substrate were oven dried $\left(105^{\circ} \mathrm{C}\right.$ for $24 \mathrm{~h}$ ) and weighed to determine volumetric water content at the time each plant was presenting signs of water stress. Root balls were cut at substrate level, washed, oven dried $\left(70^{\circ} \mathrm{C}\right.$ for $\left.48 \mathrm{~h}\right)$, and weighed. Leaves and stems were separated and leaf area was measured using a leaf area meter (Li-3100, Li-Cor Biosciences, Lincoln, NE, U.S.) then leaves, and stems were dried $\left(70{ }^{\circ} \mathrm{C}\right.$ for $\left.48 \mathrm{~h}\right)$ and dry weights recorded.

\section{Quality data}

Plant quality data, based on overall aesthetics (including water stress), were recorded for each plant every day at weighing. Quality ratings were assigned, by the same individual for consistency, on a scale of $1-5$ with $1=$ dead and $5=$ perfect health and appearance.

\section{Weather data}

Air temperature and relative humidity within the polyhouse were measured every five minutes by three data loggers (EL-USB-2-LCD+, Lascar Electronics Inc., Erie, PA) positioned on benches across the polyhouse to account for any variations. Vapor pressure deficit (VPD) was calculated in $\mathrm{kPa}$ using measured $\mathrm{T}\left({ }^{\circ} \mathrm{C}\right)$ and $\mathrm{RH}(\%)$ and the equation: $[0.61121 \times \operatorname{EXP}((17.269 \times \mathrm{T}) /(\mathrm{T}+237.3))-(0.61121 \mathrm{x}$ $\operatorname{EXP}((17.269 \times \mathrm{T}) /(\mathrm{T}+237.3)) \times \mathrm{RH} / 100)] \cdot{ }^{28}$ Evapotranspiration data was normalized using the VPD equation.

\section{Statistical analysis}

Evapotranspiration, leaf area, biomass, and quality data were analyzed using analysis of variance (ANOVA) for a mixed model. Species and water were treated as fixed effects while block was treated as a random effect. Analyses were performed using SAS 9.4 (SAS Institute, Cary, NC, U.S.A.).

\section{Results}

\section{Environment}

Average polyhouse air temperatures trended downward throughout the course of the experiments, from 28.3 to $33.1^{\circ} \mathrm{C}$ during period 1 , 19.6 to $28.9^{\circ} \mathrm{C}$ in period 2, and 8.1 to $23.5^{\circ} \mathrm{C}$ in period 3 (Figure 1). Relative humidity ranged from 56.8 to $92 \%, 58$ to $85.9 \%$, and 57.7 to $85.9 \%$ for dry down periods 1,2 , and 3 , respectively (Figure 2). Vapor pressure deficits ranged from 0.23 to $2.4 \mathrm{kPa}, 0.52$ to $1.57 \mathrm{kPa}$, and 0.28 to $1.05 \mathrm{kPa}$ (Figure 3 ).

\section{Water depletion}

In the first dry down period, C. americana and I. virginica lost water at a faster rate than all other species and exhibited signs of severe water stress most frequently by days 5 and 6 , respectively 
(Figure 4). Both C. americana and I. virginica recovered poorly compared to the remaining species as plants would experience leaf curl, dieback, and significant wilt once left to remain in the study the additional $24 \mathrm{~h}$ after the initial signs of water stress. Cornus sericea lasted until day 7 (Figure 4) and recovered well from water stress. Ilex verticillata remained in the study until day 8 (Figure 5) However, as it experienced water stress the lower leaves would dry out and abscise before showing signs of wilt. Rhus aromatica and C. sanguinea used water at a much slower rate and did not show signs of water stress until days 13 and 16, respectively (Figure 5). Rhus aromatica's inner leaves became chlorotic and then necrotic prior to wilting, while $\mathrm{C}$. sanguinea developed a blue-gray cast to its leaves in response to water stress.

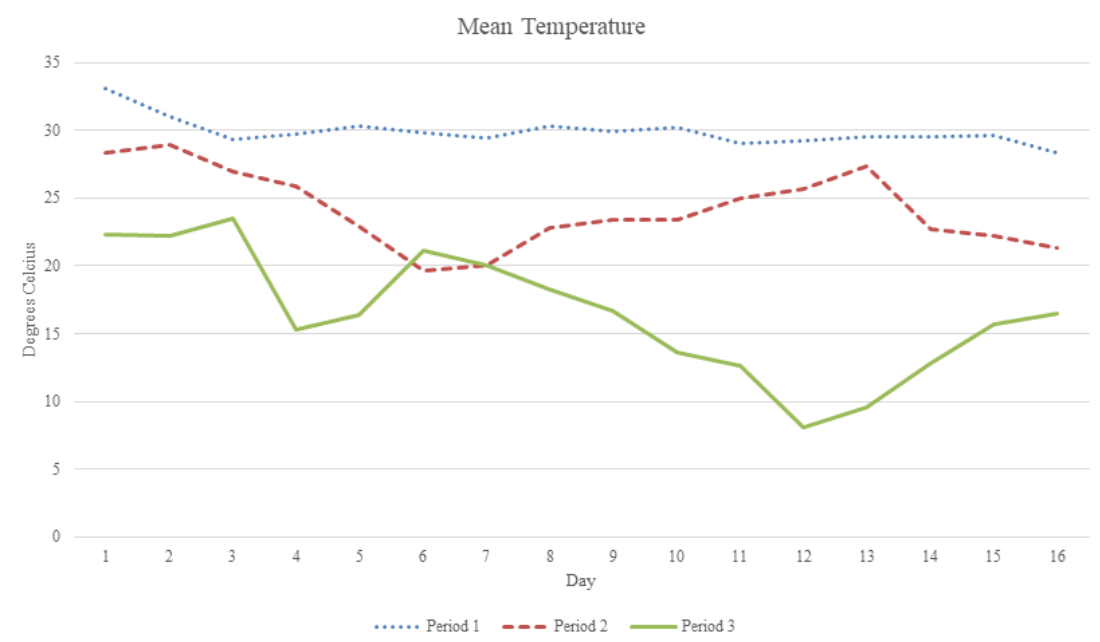

Figure I Mean temperature per day during period I (16 August-3I August), period 2 (9 September -24 September), and period 3 (7 October-23 October).

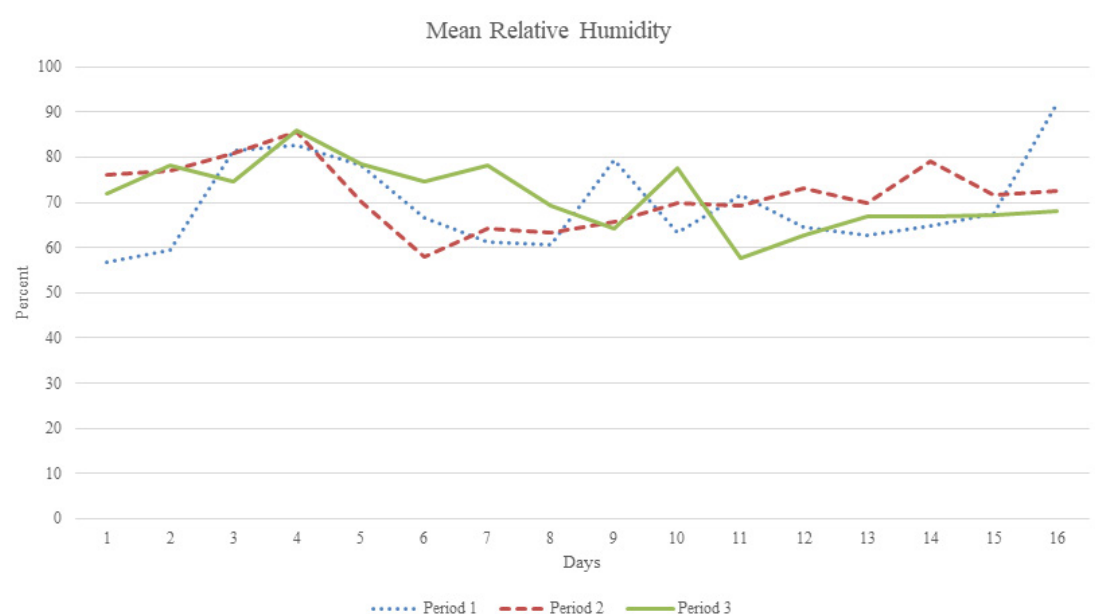

Figure 2 Mean relative humidity per day during period I (I6 August-3 I August), period 2 (9 September -24 September), and period 3 (7 October-23 October).

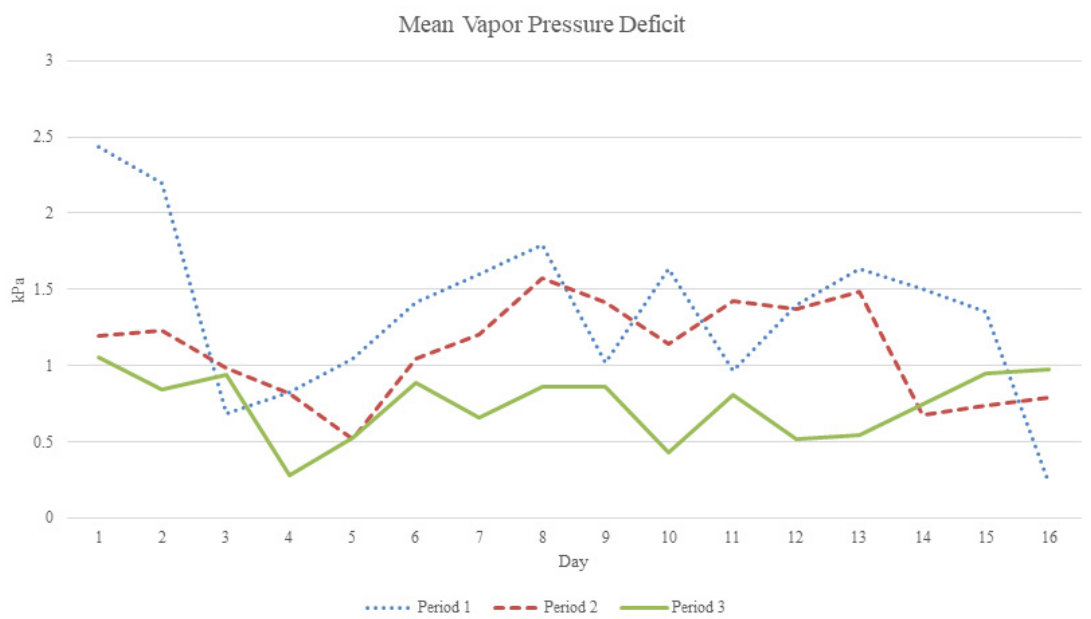

Figure 3 Mean vapor pressure deficit (VPD) per day during period I (I6 August-3 I August), period 2 (9 September-24 September), and period 3 (7 October-23 October). 

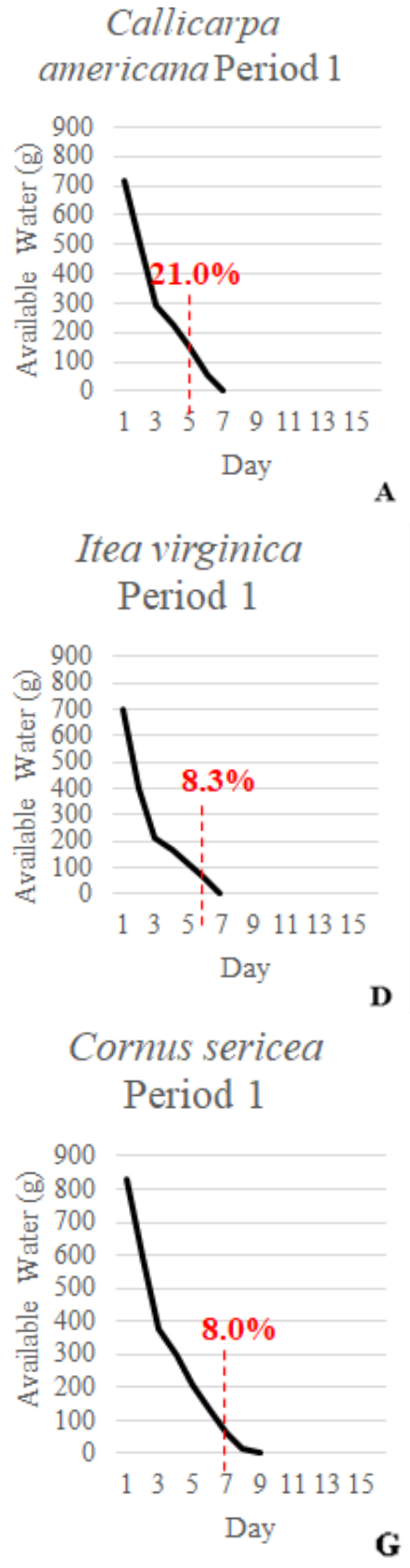

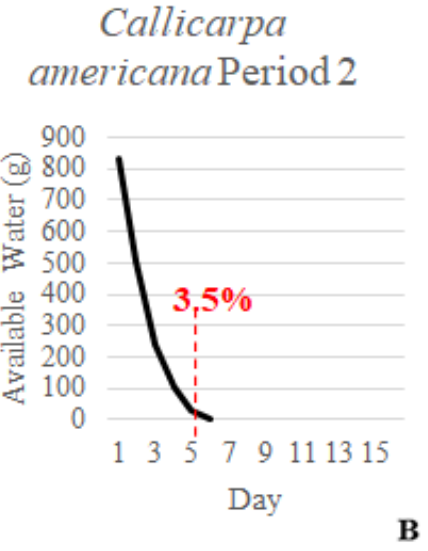

Itea virginica

Period 2

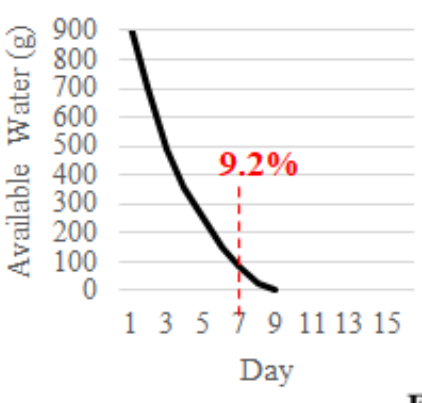

E

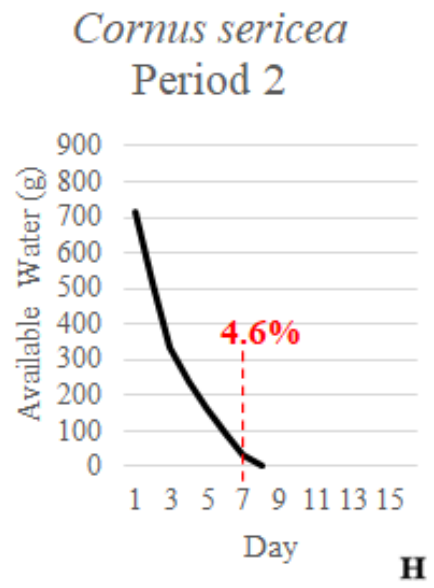

Callicarpa americana Period 3

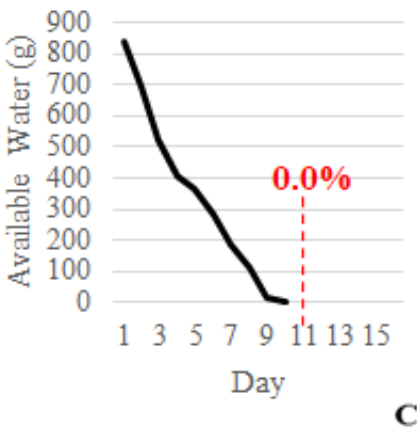

Itea virginica

Period 3

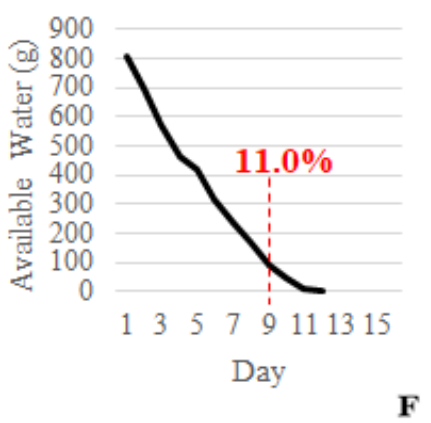

\section{Cormus sericea} Period 3

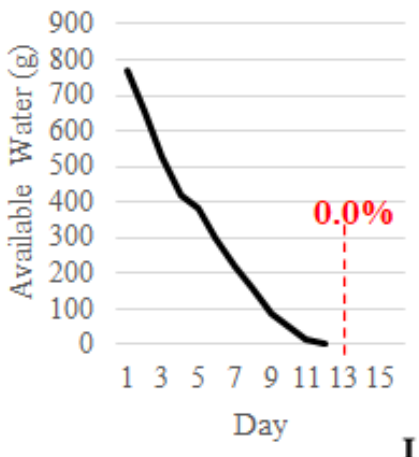

Figure 4 A-I. Graphs show the mean water depletion (evapotranspiration) curve for each species over dry down period I [I6 August-3 I August (left)], period 2 [9 September-24 September (middle)], and period 3 [7 October-23 October (right)]. Dashed lines indicate the species mode for severe signs of water stress, while percentages above dashed lines indicate the average percentage of plant available water at that time.
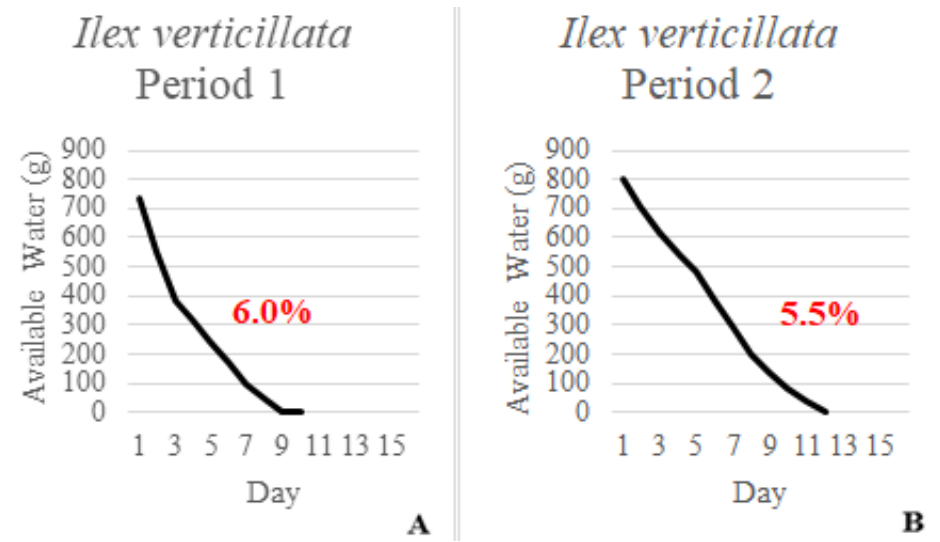

\section{Ilex verticillata \\ Period 3}

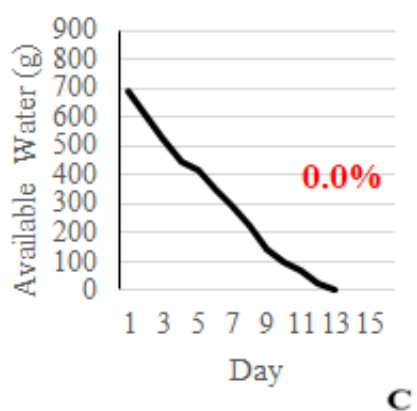

Citation: Carley DS, Gragg LA, Taggart MJ, et al. Estimation of water stress tolerance of six woody plant species. Horticult Int J. 202 I;5(2):64-72. DOI: I0.I5406/hij.202I.05.00205 

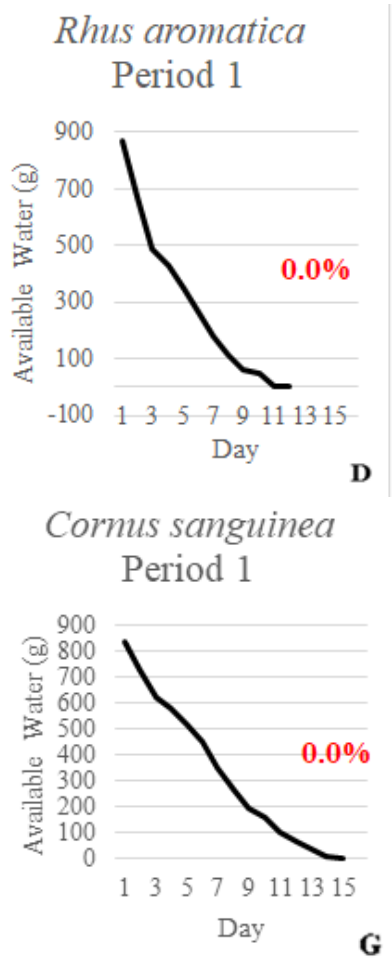

Rhus aromatica Period 2

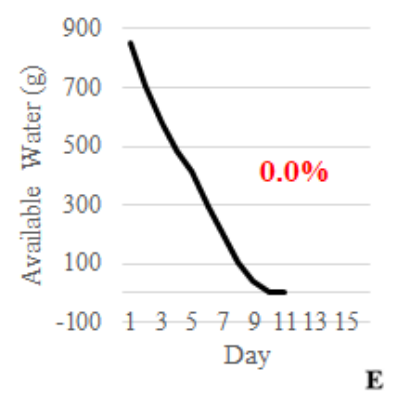

Cormus sanguinea Period 2

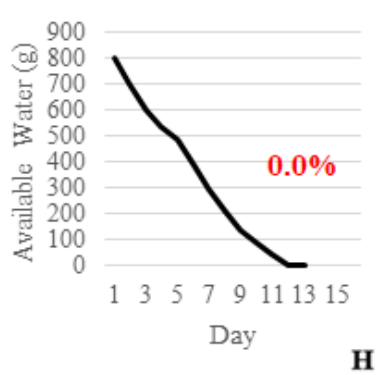

Rhus aromatica

Period 3

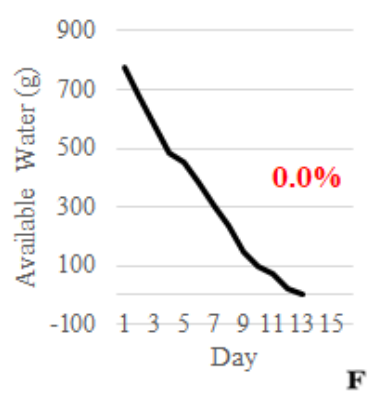

Cormus sanguinea

Period 3

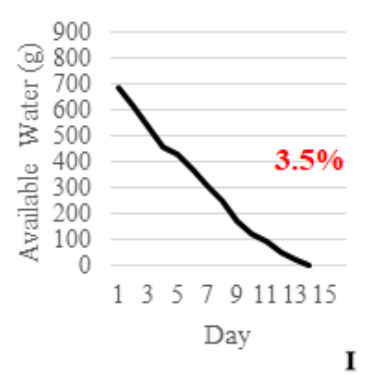

Figure 5 A-I. Graphs show the mean water depletion (evapotranspiration) curve for each species over dry down period I [I6 August-3I August (left)], period 2 [9 September-24 September (middle)], and period 3 [7 October-23 October (right)]. Dashed lines indicate the species mode for severe signs of water stress, while percentages above dashed lines indicate the average percentage of plant available water at that time.

During the second dry down period, C. americana and I. virginica continued to use water at a faster rate than all other species, showing signs of water stress on day 6 (Figure 4). Cornus sericea lasted until day 7 again (Figure 4) and I. verticillata remained in the study until day 11 (Figure 5), while R. aromatica and C. sanguinea continued to use water at a much slower rate than the other species and did not show signs of water stress until days 11 and 12, respectively (Figure $5)$.

Polyhouse air temperature declined in the third dry down period, reducing atmospheric demand for water. Observed evapotranspiration declined during this period and all species persisted longer before showing signs of water stress (Figure 4 \& Figure 5). Itea virginica lost water at a faster rate than all other species and showed symptoms of water stress on day 9, while C. americana did not show signs of water stress until day 11. (Figure 4). Cornus sericea lasted until day 9 (Figure 4) and I. verticillata day 13 (Figure 5), while R. aromatica and C. sanguinea maintained water use, not showing signs of water stress until days 12 and 13, respectively (Figure 4). Over the course of the experiment, with the exception of $\mathrm{C}$. americana during the first dry down period, all species showed signs of water stress when approximately $10 \%$ or less of plant available water remained.

\section{Size parameters}

Callicarpa americana and I. virginica had an initial spread at 37.0 and $57.5 \mathrm{~cm}$ and at study's end at 44.6 and $56.2 \mathrm{~cm}$, while maintaining significantly greater leaf areas of 2120.9 and $1744.8 \mathrm{~cm} 2$, respectively (Table 1). Cornus sanguinea was significantly smaller than C. americana and I. virginica in initial $(15.3 \mathrm{~cm})$ and final spread $(20.8$ $\mathrm{cm})$, as well as leaf area $(543.4 \mathrm{~cm} 2)$, but was significantly taller than all other species both initially $(47.5 \mathrm{~cm})$ and the study's end $(47.8$ $\mathrm{cm})$. The height and spread of R. aromatica was not significantly different from C. americana or I. virginica. Callicarpa americana and I. virginica did have significantly greater leaf area than $\mathrm{R}$. aromatic with $1408.1 \mathrm{~cm} 2$. Ilex verticillata was consistently, significantly smaller across all growth measurements with $26.3 \mathrm{~cm}$ initial height, $25.2 \mathrm{~cm}$ final height, $22.9 \mathrm{~cm}$ initial spread, $22.5 \mathrm{~cm}$ final spread, and a leaf area of $353.7 \mathrm{~cm} 2$.

Table I Average plant size and leaf area parameters across species at the beginning of period I [(initial) I6 August-3 I August] through the end of period 3 [(final) 7 October-23 October]

\begin{tabular}{llllll}
\hline \multicolumn{2}{l}{ Mean plant size measurements } & & & \\
\cline { 2 - 6 } & Initial height & Initial spread & Final height & Final spread & Leaf areay \\
\cline { 2 - 6 } Species & $\mathbf{( c m}) \pm \mathbf{S E}$ & $\mathbf{( c m}) \pm \mathbf{S E}$ & $\mathbf{( c m}) \pm \mathbf{S E}$ & $\mathbf{( c m}) \pm \mathbf{S E}$ & $\left.\mathbf{( c m}^{2}\right) \pm \mathbf{S E}$ \\
\hline Callicarpa americana & $24.6 \pm 0.8 \mathrm{dz}$ & $37.0 \pm 0.8 \mathrm{ab}$ & $27.8 \pm 2.2 \mathrm{c}$ & $44.6 \pm 2.4 \mathrm{~b}$ & $2120.9 \pm 246.2 \mathrm{a}$ \\
Itea virginica & $32.5 \pm 1.9 \mathrm{c}$ & $56.5 \pm 2.0 \mathrm{a}$ & $30.0 \pm 2.3 \mathrm{c}$ & $56.2 \pm 1.5 \mathrm{a}$ & $1744.8 \pm 218.4 \mathrm{a}$ \\
Cornus sericea & $41.5 \pm 1.7 \mathrm{~b}$ & $34.6 \pm 3.0 \mathrm{c}$ & $40.0 \pm 3.3 \mathrm{~b}$ & $36.2 \pm 4.4 \mathrm{~b}$ & $841.8 \pm 140.9 \mathrm{bc}$ \\
Ilex verticillata & $26.3 \pm 1.8 \mathrm{~d}$ & $22.9 \pm 1.4 \mathrm{~d}$ & $25.2 \pm 1.5 \mathrm{c}$ & $22.5 \pm 1.6 \mathrm{c}$ & $353.7 \pm 91.4 \mathrm{c}$ \\
\hline
\end{tabular}


Table Continued..

\begin{tabular}{|c|c|c|c|c|c|}
\hline \multicolumn{6}{|c|}{ Mean plant size measurements } \\
\hline \multirow[b]{2}{*}{ Species } & Initial height & Initial spread & Final height & Final spread & Leaf areay \\
\hline & $(\mathrm{cm}) \pm S E$ & $(\mathrm{~cm}) \pm S E$ & $(\mathrm{~cm}) \pm S E$ & $(\mathrm{~cm}) \pm S E$ & $\left(\mathrm{~cm}^{2}\right) \pm \mathrm{SE}$ \\
\hline Rhus aromatica & $27.7 \pm 2.2 \mathrm{~cd}$ & $38.4 \pm 3.6 b c$ & $29.6 \pm 2.3 c$ & $37.9 \pm 2.3 b$ & $\mid 408.1 \pm 466.3 b$ \\
\hline Cornus sanguinea & $47.5 \pm 3.2 \mathrm{a}$ & $15.3 \pm 3.1 \mathrm{~d}$ & $47.8 \pm 1.2 \mathrm{a}$ & $20.8 \pm 2.3 c$ & $543.4 \pm 67.6 c$ \\
\hline$p$-value & $<.0001$ & $<.0001$ & $<.0001$ & $<.0001$ & $<.0001$ \\
\hline
\end{tabular}

y Means presented for leaf area taken at the end of period 3

zMeans the same letters following are not significantly different according to Fisher's Protected LSD test at $\alpha \leq 0.05$

\section{Initial water use}

The rate of evapotranspiration per unit VPD increased in both the second and third dry down periods for all species with the highest rate occurring during the second period (Table 2). The rate of evapotranspiration/VPD was consistently and significantly higher in
C. americana across all dry down periods at $92.29 \mathrm{~g} / \mathrm{kPa}$ during period one, $245.6 \mathrm{~g} / \mathrm{kPa}$ during period two, and $169.8 \mathrm{~g} / \mathrm{kPa}$ during period three. Conversely, C. sanguinea maintained a significantly lower rate of water use in periods one, two, and three using $46.9 \mathrm{~g} / \mathrm{kPa}, 82.1 \mathrm{~g} /$ $\mathrm{kPa}$, and $83.1 \mathrm{~g} / \mathrm{kPa}$ respectively (Table 3 ).

Table 2 Average water loss per unit Vapor Pressure Deficit (VPD) for each dry down period across species

\begin{tabular}{|c|c|c|c|}
\hline \multicolumn{4}{|c|}{ Mean initial water use per unit VPDy } \\
\hline \multirow[b]{2}{*}{ Species } & Period I & Period 2 & Period 3 \\
\hline & $(\mathrm{g} / \mathrm{kPa}) \pm \mathrm{SE}$ & $(\mathrm{g} / \mathrm{kPa}) \pm \mathrm{SE}$ & $(g / k P a) \pm S E$ \\
\hline Callicarpa americana & $92.3 \pm 3.9 \mathrm{az}$ & $245.6 \pm 6.3 \mathrm{a}$ & $169.8 \pm 11.1 \mathrm{a}$ \\
\hline Itea virginica & $104.9 \pm 3.9 \mathrm{a}$ & $175.7 \pm 21.7 b$ & $125.9 \pm 16.4 b$ \\
\hline Cornus sericea & $97.6 \pm 4.5 \mathrm{a}$ & $152.0 \pm 11.5 b$ & $127.9 \pm 14.5 b$ \\
\hline Ilex verticillata & $76.3 \pm 3.9 b$ & $77.9 \pm 10.1 \mathrm{c}$ & $87.4 \pm 11.8 c$ \\
\hline Rhus aromatica & $82.5 \pm 4.1 \mathrm{~b}$ & $112.1 \pm 12.8 \mathrm{c}$ & $105.6 \pm 13.3 \mathrm{~b}$ \\
\hline Cornus sanguinea & $46.9 \pm 3.8 c$ & $82.1 \pm 7.3 \mathrm{c}$ & $83.1 \pm 5.9 c$ \\
\hline $\mathrm{p}$-value & 0.0001 & 0.0001 & 0.0002 \\
\hline
\end{tabular}

y Means presented for the initial 2 days of each dry down period

zMeans with the same letters following are not significantly different according to Fisher's Protected LSD test at $\alpha \leq 0.05$

Table 3 Average quality ratings for each species over each dry down period

\begin{tabular}{|c|c|c|c|c|c|c|c|c|c|}
\hline \multicolumn{10}{|c|}{ Mean quality ratings $(\mathrm{I}-5) \mathrm{w}$} \\
\hline \multirow[b]{2}{*}{ Species } & \multicolumn{3}{|c|}{ Period I } & \multicolumn{3}{|c|}{ Period 2} & \multicolumn{3}{|c|}{ Period 3} \\
\hline & Startx & $\begin{array}{l}\text { WS } \\
\text { signsy }\end{array}$ & Wilted & Initial & $\begin{array}{l}\text { WS } \\
\text { signs }\end{array}$ & Wilted & Initial & $\begin{array}{l}\text { WS } \\
\text { Signs }\end{array}$ & Wilted \\
\hline $\begin{array}{l}\text { Callicarpa } \\
\text { americana }\end{array}$ & $\begin{array}{l}4.57 \pm \\
0.07 \mathrm{ab}\end{array}$ & $\begin{array}{l}4.21 \pm \\
0.13 \mathrm{ab}\end{array}$ & $\begin{array}{l}3.00 \pm \\
0.15 \mathrm{ab}\end{array}$ & $\begin{array}{l}4.07 \pm \\
0.23 z\end{array}$ & $\begin{array}{l}3.5 \pm \\
0.18 \mathrm{a}\end{array}$ & $\begin{array}{l}2.86 \pm \\
0.09 b\end{array}$ & $\begin{array}{l}3.93 \pm \\
0.05\end{array}$ & $\begin{array}{l}3.42 \pm \\
0.15 \mathrm{a}\end{array}$ & $\begin{array}{l}2.79 \pm \\
0.17 b\end{array}$ \\
\hline Itea virginica & $\begin{array}{l}4.43 \pm \\
0.07 \mathrm{ab}\end{array}$ & $\begin{array}{l}3.71 \pm \\
0.15 \mathrm{bc}\end{array}$ & $\begin{array}{l}2.86 \pm \\
0.09 b\end{array}$ & $\begin{array}{l}3.86 \pm \\
0.38\end{array}$ & $\begin{array}{l}3.25 \pm \\
0.11 \mathrm{a}\end{array}$ & $\begin{array}{l}2.79 \pm \\
0.10 b\end{array}$ & $\begin{array}{l}3.64 \pm \\
0.21\end{array}$ & $\begin{array}{l}3.5 \pm \\
0.18 \mathrm{a}\end{array}$ & $\begin{array}{l}3.00 \pm \\
0.11 b\end{array}$ \\
\hline Cornus sericea & $\begin{array}{l}3.86 \pm \\
0.14 c\end{array}$ & $\begin{array}{l}3.55 \pm \\
0.15 \mathrm{c}\end{array}$ & $\begin{array}{l}2.93 \pm \\
0.13 b\end{array}$ & $\begin{array}{l}3.64 \pm \\
0.14\end{array}$ & $\begin{array}{l}2.82 \pm \\
0.32 b\end{array}$ & $\begin{array}{l}2.39 \pm \\
0.11 \mathrm{c}\end{array}$ & $\begin{array}{l}3.57 \pm \\
0.15\end{array}$ & $\begin{array}{l}2.86 \pm \\
0.11 \mathrm{~b}\end{array}$ & $\begin{array}{l}2.39 \pm \\
0.13 c\end{array}$ \\
\hline Ilex verticillata & $\begin{array}{l}4.79 \pm \\
0.10 a\end{array}$ & $\begin{array}{l}4.14 \pm \\
0.09 a\end{array}$ & $\begin{array}{l}3.36 \pm \\
0.14 \mathrm{a}\end{array}$ & $\begin{array}{l}4.07 \pm \\
0.28\end{array}$ & $\begin{array}{l}3.61 \pm \\
0.21 \mathrm{a}\end{array}$ & $\begin{array}{l}3.29 \pm \\
0.15 \mathrm{ab}\end{array}$ & $\begin{array}{l}3.93 \pm \\
0.32\end{array}$ & $\begin{array}{l}3.61 \pm \\
0.27 \mathrm{a}\end{array}$ & $\begin{array}{l}3.50 \pm \\
0.27 \mathrm{ab}\end{array}$ \\
\hline Rhus aromatica & $\begin{array}{l}4.43 \pm \\
0.13 b\end{array}$ & $\begin{array}{l}3.96 \pm \\
0.11 \mathrm{ab}\end{array}$ & $\begin{array}{l}3.43 \pm \\
0.17 \mathrm{a}\end{array}$ & $\begin{array}{l}4.36 \pm \\
0.09\end{array}$ & $\begin{array}{l}3.67 \pm \\
0.10 \mathrm{a}\end{array}$ & $\begin{array}{l}3.43 \pm \\
0.13 \mathrm{a}\end{array}$ & $\begin{array}{l}3.71 \pm \\
0.22\end{array}$ & $\begin{array}{l}3.36 \pm \\
0.20 \mathrm{a}\end{array}$ & $\begin{array}{l}3.21 \pm \\
0.24 \mathrm{ab}\end{array}$ \\
\hline $\begin{array}{l}\text { Cornus } \\
\text { sanguinea }\end{array}$ & $\begin{array}{l}4.57 \pm \\
0.07 \mathrm{ab}\end{array}$ & $\begin{array}{l}4.00 \pm \\
0.11 \mathrm{ab}\end{array}$ & $\begin{array}{l}3.64 \pm \\
0.14 a\end{array}$ & $\begin{array}{l}4.29 \pm \\
0.15\end{array}$ & $\begin{array}{l}3.57 \pm \\
0.11 \mathrm{a}\end{array}$ & $\begin{array}{l}3.11 \pm \\
0.11 \mathrm{ab}\end{array}$ & $\begin{array}{l}4.00 \pm \\
0.15\end{array}$ & $\begin{array}{l}3.86 \pm \\
0.11 \mathrm{a}\end{array}$ & $\begin{array}{l}3.61 \pm \\
0.35 \mathrm{a}\end{array}$ \\
\hline p-value & $<.0001$ & 0.0084 & 0.0013 & 0.086 & 0.0011 & $<.0001$ & 0.5223 & 0.0213 & 0.0007 \\
\hline
\end{tabular}

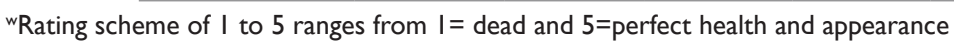

×Means presented on a scale of $\mathrm{I}-5 \pm \mathrm{SE}$

'The point when each plant began showing signs of water stress

zMeans without letters or the same letters following are not significantly different according to Fisher's Protected LSD test at $\alpha \leq 0.05$

Citation: Carley DS, Gragg LA, Taggart MJ, et al. Estimation of water stress tolerance of six woody plant species. Horticult Int J. 202I;5(2):64-72.

DOI: I0.I5406/hij.202I.05.00205 


\section{Discussion}

This study builds on previous work to evaluate the suitability of different woody plants commonly planted in the Southeastern United States for use in water-deficient urban environments based on VPD. The rate of water depletion considers the average rate at which water is lost to evapotranspiration while initial water use takes into account the average initial rate of water use under well-watered conditions for each species while normalized by VPD. Both water depletion rates and initial water use measurements are good predictors of drought tolerance.

Water depletion and initial water use results clearly indicate species differences to water stress with I. virginica and C. americana being the least drought tolerant, $\mathrm{C}$. sericea and I. verticillata having moderate drought tolerance, and R. aromatica and C. sanguinea the most drought tolerance. Although signs of water stress varied among species and each species demonstrated different physiological methods for coping with drought stress, the drought avoidance mechanism was employed by nearly all species through leaf senescence and in some cases, leaf area adjustments. Other research ${ }^{29}$ notes that wilt, leaf curl, and premature leaf senescence are all effective physiological methods of reducing transpiration. An increase in average initial water use occurred among all species from period 1 to period 2 and period 1 to period 3 even though VPD had decreased by period 3. This likely was the result of damage and repair cycles as plants experienced the series of dry downs.

All species, with the exception of C. sanguinea, displayed wilting followed by minor $(\leq 50 \%)$ leaf abscission as water stress developed. Though leaf area measurements were not taken until the end of the study, I. virginica and C. americana's rapid water depletion and greater initial water use rates across dry down periods is likely attributed to their greater transpirable surface areas compared to all other species. Each of these species demonstrated signs of drought avoidance through leaf curl prior to wilting, a physiological response that which has been well documented. In other studies, this change in leaf orientation has been attributed to a decrease in the amount of transpirable surface area directly exposed to transpiration increasing factors such as sunlight and wind. ${ }^{30,31}$ Cornus sericea's moderate water depletion rates and simply wilting in response to water stress indicate that C. sericea did not display signs of drought avoidance or drought tolerance and would have intermediate drought resistance in water uncertain environments. While I. verticillata is native to wetlands and withstands periods of flooding well, ${ }^{32}$ it was a moderate water user with only a marginally slower rate of water depletion compared to I. virginica or C. americana. This was demonstrated as nearly half of their leaves senesced during period 1 , potentially making subsequent dry down periods less representative of how I. verticillata uses water during drought, however, leaves abscised in response to water stress may have been a means of drought avoidance by reducing transpirable surface area. Our findings are similar to those of Niinemets and Valladares (2006), which ranked I. verticillata as a 2 on a drought tolerance scale of 0 (no tolerance) to 5 (maximal tolerance), suggesting I. verticillata would perform marginally better in urban areas that are or will experience periods of drought than C. americana and I. virginica. Rhus aromatica consistently maintained conservative rates of water depletion and initial water use across all dry down periods, suggesting greater water use efficiency. Rhus aromatica's physiological response of chlorotic to necrotic leaves indicates signs of drought tolerance as it made adjustments to osmotic potential through the accumulation of solutes from these leaves to maintain turgor pressure throughout the rest of the plant. ${ }^{30,33,34}$ Other research had demonstrated that the genus Rhus has higher rates of water use efficiency and is relatively water stress tolerant. ${ }^{13,35}$

Throughout the study, C. sanguinea maintained the slowest rate of water depletion and demonstrated one of the lowest initial water use measurements compared to the five other species. Of all of the species tested in the study, it was also the only species to develop a grayish-blue cast to the leaves instead of wilting. Though more common among turfgrass species, this symptom is typically indicative of prolonged stomatal closure (drought avoidance) and drought tolerance through osmotic adjustment. ${ }^{36,37}$ Cornus sanguinea's lower rates of water depletion and initial water use indicate greater water use efficiency and drought tolerance.

With the exception of R. aromatica, all species included in this study have been recommended for planting in rain gardens ranging from North Carolina to New York. ${ }^{38-44}$ Callicarpa americana, I. virginica, and I. verticillata have been recommended for use from Florida to New York. ${ }^{38-42}$ Despite recommendations that suggest these species will perform well during periods of flooding and prolonged periods of drought, our results indicate otherwise. Most notably, I. virginica and $\mathrm{C}$. americana, demonstrated the lowest drought tolerance and highest rates of water use of the species evaluated in this study. Of these species, R. aromatica is the only species native to dry, open, rocky locations ${ }^{43}$ and appears to be well suited for water-deficient urban environments. Though C. sanguinea prefers well drained sites, our research suggests it is also well suited for water stressed urban environments. All remaining species are native to poorly drained wetlands and swamps. ${ }^{44-46}$ Provenance is another key factor that should be considered when selecting plants for functional uses, such as in rain gardens or bio-retention systems.

\section{Conclusion}

There is very little research-based data on water use of woody plant species. Other studies have examined the drought tolerance of several species; however, much work still remains to be done (Garcia-Navarro et al., 2004; Montague et al., 1998; Scheiber et al., 2008; Warsaw et al., 2009; Zollinger et al., 2006). The use of VPD to evaluate the drought tolerance of woody plants appears to effectively normalize water use rates, accounting for the environment. With increased concern of increasing drought conditions due to climate change, native plants are being used planted in communities that consistently have too little water or strict water restrictions. This research provides evidenced-based drought tolerance data on six commonly planted landscape plants. Further research is needed on additional species, as well as, a field study examining these same species in the landscape.

\section{Acknowledgments}

The authors would like to thank the North Carolina State Center for Turfgrass Environmental Research and Education for providing funding for this research. Many thanks are extended to Phil Hatfield and Tim Ketchie for their assistance in carrying out this research. In addition, the authors would like to thank the Horticulture Field Laboratory in Raleigh, NC for providing space and assistance.

\section{Conflicts of interest}

The authors have no conflict of interest for this research. 


\section{References}

1. USEPA. 2015. Climate change indicators in the United States. United States environmental protection agency. 2016.

2. USEPA, Water sense ${ }^{\circledR}$ An EPA partnership program. United States environmental protection agency. 2016.

3. Fishman C. The big thirst: the secret life and turbulent future of water. Simon and Schuster. New York, New York; 2011.

4. JiaChuan Y, ZhiHua W. Planning for a sustainable desert city: the potential water buffering capacity of urban green infrastructure. Landscape and Urban Planning. 2017;167:339-347.

5. Chow WTL, Brazel AJ. Assessing xeriscaping as a sustainable heat island mitigation approach for a desert city. Build Environ. 2012;47:170-181.

6. Davis, AP, Hunt WF, Traver RG, et al. Bioretention technology: overview of current practice and future needs. J Environ Eng. 2009;135(3):109-117.

7. Begg JE, TurnerNC.Cropwaterdeficits.AdvAgron. 1976;28(161217.1976).

8. Zollinger N, Kjelgren R, Cerny-Koenig T, et al. Drought responses of six ornamental herbaceous perennials. Scientia Hortic-Amsterdam 2006;109(3):267-274.

9. Fischer R, Turner NC. Plant productivity in the arid and semiarid zones. Annu Rev of Plant Physiol. 1978;29(1):277-317.

10. Kramer P. Water relations of plants. Academic Press, San Diego, CA. 1983. 489pp.

11. St. Hilaire R, Arnold MA, Wilkerson DC, et al. Efficient water use in residential urban landscapes. HortScience. 2008;43(7):2081-2092.

12. Miralles-Crespo J, Sánchez-Blanco MJ, Navarro A, et al. Comparison of stem diameter variations in three small ornamental shrubs under water stress. HortScience 2010;45(11):1681-1689.

13. Montague T, Kjelgren R, Rupp L. Surface energy balance affects gas exchange of three shrub species. J Arboric. 1998;24(5):254.

14. Anderson DB. Relative humidity or vapor pressure deficit. Ecology 1936;17(2):277-282.

15. Campbell GS, Norman JM. An introduction to environmental biophysics, 2nd edition. Springer, New York; 1998.

16. Cregg, BM, Dix ME. Tree moisture stress and insect damage in urban areas in relation to heat island effects. $J$ Arboric. 2001;27(1):8-17.

17. Montague T, Kjelgren R, Rupp L. Surface energy balance affects gas exchange and growth of two irrigated landscape tree species in an arid climate. J Am Soc Hort Sci. 2000;125(3):299-309.

18. Schoppach R, Sadok W. Differential sensitivities of transpiration to evaporative demand and soil water deficit among wheat elite cultivars indicate different strategies for drought tolerance. Environ Exp Bot. 2012;84:1-10.

19. Gholipoor M, Prasad PV, Mutava, RN, et al. Genetic variability of transpiration response to vapor pressure deficit among sorghum genotypes. Field Crop Res. 2010;119(1):85-90.

20. Medina V, Gilbert ME. Physiological trade-offs of stomatal closure under high evaporative gradients in field grown soybean. Funct. Plant Biol. 2016;43(1):40-51.

21. Devi MJ, Sadok W, Sinclair TR. Transpiration response of de-rooted peanut plants to aquaporin inhibitors. Environ Exp Bot. 2012;78:167-172.

22. Sermons SM, Seversike TM, Sinclair TR, et al. Temperature influences the ability of tall fescue to control transpiration in response to atmospheric vapour pressure deficit. Funct. Plant Biol. 2012;39(12):979-986.
23. García-Navarro MC, Evans RY, Montserrat RS. Estimation of relative water use among ornamental landscape species. Scientia HorticAmsterdam. 2004;2(99):163-174.

24. Niinemets Ü, Valladares F. Tolerance to shade, drought, and waterlogging of temperate northern hemisphere trees and shrubs. Ecol Monogr. 2006;76(4):521-547.

25. Scheiber S, Gilman E, Sandrock D, et al. Postestablishment landscape performance of Florida native and exotic shrubs under irrigated and nonirrigated conditions. Hort Tech. 2008;18(1):59-67.

26. Warsaw AL, Fernandez RT, Cregg BM, et al. Water conservation, growth, and water use efficiency of container-grown woody ornamentals irrigated based on daily water use. HortScience 2009;44(5):1308-1318.

27. Montague DT, Bates A. Response of two field-grown maple (Acer) species to reduced irrigation in a high vapor pressure, semi-arid climate. Arboric Urban For. 2015;41(6):334-345.

28. Allen RG, Pereira, LS, Raes, D, et al. Crop evapotranspiration-guidelines for computing crop water requirements-fao irrigation and drainage paper 56. FAO Rome. 1998;300(9):D05109.

29. Kozlowski TT, Kramer PJ, Pallardy SG. The physiological ecology of woody plants. Mooney HA, editor. 1st ed. San Diego, California: Academic Press. 1991;267, 279, 292.

30. Gibeault VA, Henry M, Cockerham S, et al. Managing turfgrasses during drought. University of California (system). Division of agriculture and natural resources. Leaflet. no. 21499;1991

31. Sherratt P, Danneberger K. Drought resistance. 2016.

32. Jernigan KJ, Wright AN. Effect of repeated short interval flooding events on root and shoot growth of four landscape shrub taxa. J. of Environ. Hort. 2011;29(4):220.

33. Pallardy SG. Physiology of woody plants. Academic Press. 2010;346366.

34. Touchette BW, Iannacone LR, Turner GE, et al. Drought tolerance versus drought avoidance: a comparison of plant-water relations in herbaceous wetland plants subjected to water withdrawal and repletion. Springer, Dordrecht; The Netherlands. 2007.

35. Ninemets U, Valladres F. Tolerance to shade, drought, and waterlogging of temperate northern hemisphere trees and shrubs. Eco Monographs 2006;76(4)521-547.

36. Carroll M. Management strategies to forestall drought induced dormancy of Kentucky bluegrass. Grounds \& Commercial Turf Session Papers. 1999;196-199.

37. Hinckley T, Duhme F, Hinckley A, et al. Water relations of drought hardy shrubs: osmotic potential and stomatal reactivity. Plant, Cell \& Environ. 1980;3(2):131-140.

38. Dropkin EM, Bassuk N, Signorelli T. Woody shrubs for stormwater retention practices. 2016.

39. Glen C. Plants for rain gardens: recommended for Central North Carolina. North Carolina State Cooperative Extension-New Hanover County Center. 2016a.

40. Glen C. Plants for rain gardens: recommended for Southeastern North Carolina. North Carolina State Cooperative Extension-New Hanover County Center. 2016b.

41. Glen C. Plants for rain gardens: recommended for Western North Carolina. North Carolina State Cooperative Extension-New Hanover County Center. 2016c.

42. Post A. Rain gardens: plant selection and maintenance. University of Florida/Institute of Food and Agriculture Services. Sarasota County Extension Service. 2010. 
43. Wynia R. Plant fact sheet for fragrant sumac (Rhus aromatic var. serotina) USDA-natural resources conservation service, Plant Materials Center. Manhattan, KS. 2011.

44. Connor KF. Cornus sericea. In: Francis, John K, editors. Wildland Shrubs of the United States and its territories: Thamnic. Gen. Tech. Rep. San Juan, Puerto Rico: U.S. Department of Agriculture, Forest Service, International Institute of Tropical Forestry, and Fort Collins, CO: U.S Department of Agriculture, Forest Service, Rocky Mountain Research Station: 2004a;1(26):249-251.
45. Connor KF. Itea virginica. Wildland Shrubs of the United States and its territories: Thamnic. Gen. Tech. Rep. San Juan, Puerto Rico: U.S. Department of Agriculture, Forest Service, International Institute of Tropical Forestry, and Fort Collins, CO: U.S. Department of Agriculture, Forest Service, In: Francis, John K, editors. Rocky Mountain Research Station: 2004b;1(26):391-392.

46. Pijut PM. Cornus sericea. Wildland shrubs of the United States and its territories. Thamnic. Gen. Tech. Rep. Rio Piedras, Puerto Rico: U.S. Department of Agriculture, Forest Service, In: Francis, John K, editors. International Institute of Tropical Forestry. 2004;1(26):249-251. 